\title{
Ataturk: Lessons in Leadership from the Greatest General of the Ottoman Empire. By Austin Bay. (New York, N.Y.: Palgrave- McMillan, 2011)
}

Mark Roberts

Transportation Security Administration

Follow this and additional works at: https://digitalcommons.usf.edu/jss pp. 89-92

\section{Recommended Citation}

Roberts, Mark. "Ataturk: Lessons in Leadership from the Greatest General of the Ottoman Empire. By Austin Bay. (New York, N.Y.: Palgrave- McMillan, 2011)." Journal of Strategic Security 5, no. 1 (2012) : 89-92.

DOI: http://dx.doi.org/10.5038/1944-0472.5.1.7

Available at: https://digitalcommons.usf.edu/jss/vol5/iss1/2

This Book Review is brought to you for free and open access by the Open Access Journals at Digital Commons @ University of South Florida. It has been accepted for inclusion in Journal of Strategic Security by an authorized editor of Digital Commons @ University of South Florida. For more information, please contact digitalcommons@usf.edu. 


\section{Ataturk: Lessons in Leadership from the Greatest General of the Ottoman Empire. By Austin Bay. (New York, N.Y.: Palgrave- McMillan, 2011)}




\section{Ataturk: Lessons in Leadership from the Greatest General of the Ottoman Empire. By Austin Bay. New York, N.Y.: Palgrave- McMillan, 2011. ISBN: 978-0-230-10711-3. Maps. Photographs. Bibliography. Notes. Index. Pp. xiv, 202. \$23.oo.}

Mustafa Kemal Ataturk remains a towering figure linking the last days of the Ottoman Empire to the founding of the modern Turkish republic. Austin Bay paints a compelling portrait of a leader who took decisive action during one of the most deadly conflicts the world had seen (World War I). He shows Ataturk as a leader, strategist, soldier, and statesman-a man who possessed and displayed great physical and moral courage.

This biography covers Ataturk's early life, military career, exploits during WWI, and the days leading up to the founding of the modern Turkish Republic. The fact that Bay left out Ataturk's leadership of modern Turkey after founding the Republic is the book's biggest shortcoming. Mustafa Kemal achieved just as much, if not more, as a civilian leader than as a military one. The author mentions in passing his exploits as a civilian leader: he abolished the caliphate, emancipated women, embraced Western clothing, Latinized the Turkish alphabet, created a secular state, and brought about a Western-style parliamentary democracy, all within a few years. This passing mention cries out for more detail, but the focus of the book remains exclusively on his military exploits.

Throughout, the author attempts to tie Ataturk's situation in a given moment to the present U.S. circumstance vis-à-vis al-Qaida and the Taliban. Unfortunately, the contexts do not overlap or have much relevance, resulting in a hollow comparison. The overall narrative is uneven, sometimes plodding, sometimes exquisitely poetic. All through the book, Bay discusses a particular occurrence, then pulls back and explains its significance in the larger context of what it would mean for future developments in either Ataturk's military career or the fate of the Ottoman Empire. The work's main strength is showing, through detailed analysis, how tactical decisions impact strategic outcomes.

Well-written and erudite, the book shows Ataturk deciding early in life to pursue a military career, with all its honor, glory, and benefits. He saw the Ottoman Empire's decline and the last caliphate (the "sick man of Europe"), and studied myriad historical examples to halt this decay. At

Journal of Strategic Security 
Journal of Strategic Security, Vol. 5, No. 1

Journal of Strategic Security

the Turkish War College, he was exposed to European and Asian influences. Displaying ability and intelligence as a young cadet, he studied Napoleon, guerrilla warfare, strategy, and tactics. Readings on the French Revolution caused him to wonder if Muslim modernity might be better attained through a more constructive type of Napoleonic figure. He saw that newer technologies could help move Ottoman strategic goals forward, but the Sultan did not want the infection of new, non-Muslim ideas that would accompany such technology. Devouring these new ideas, especially European constitutionalism, Ataturk observed that enhanced cultural awareness could bring about positive changes in the Ottoman Empire and the Caliphate. Perhaps it should be noted that although a good student with many virtues, he was not above the usual human vices; Ataturk was both a drinker and womanizer.

In his first assignment, he served in Syria, demonstrating a capacity for accepting responsibility and exercising authority in uncertain circumstances and with little guidance. Disdaining the rampant corruption of the Ottomans and disgusted with the status quo, Ataturk established networks of like-minded individuals, which led to his exile to Libya. In North Africa, he won acclaim through his personal magnetism, speaking skills, and oratory. He mastered the technology available to him at the time, effectively using the telegraph to communicate mission-essential information, as well as propaganda to shape, mold, and influence perceptions.

In his quest to professionalize the Turkish army, Ataturk played an active role in defining and writing operational doctrine. Influenced by the French use of aviation as a military asset, he sought to modernize Ottoman doctrine and strategy. As he fought against the Italians in Libya, he learned firsthand how to apply previously studied theories on psychological and guerrilla warfare. He emphasized discipline, integrity, leading by example, personal presence among his subordinates to rally and inspire them, and holding individuals accountable. In the Balkan wars preceding WWI, he fused training, intelligence, logistics, communications, and general staff functions.

Ataturk's trenchant observations of Ottoman military tactics prepared him for the coming "war to end all wars." He identified a systemic failure: an army riddled with ill-prepared, unreflective leaders who, instead of building trust between themselves and their subordinates, used discord as a management tool. He saw little commitment to military professionalism; patriotism for these officers was a hollow ritual. Rank to them meant higher pay and social prestige, not an increasing level of responsibility. Whether harsh martinets or lazy careerists, they were decadent men. Ataturk believed a competent military leader must have an unwavering 
commitment to duty, demonstrating it through self-discipline, intellectual preparation, and constant good judgment (83).

Given a hollow command during WWI, he created a unit from nothing and refused to take no for an answer. At the critical battle for Gallipoli, Ataturk serendipitously happened upon an Australia-New Zealand Army Corps (ANZAC) advance. Halting the fleeing Turkish soldiers, he formed them into a defensive line. When told his soldiers had no ammunition, he ordered them to lie down and fix their bayonets, buying time for reinforcements. The ANZACs imitated their Ottoman counterparts and lay down with fixed bayonets as well, halting their forward momentum while remaining unaware their opponents had no ammunition. Ataturk took charge of the Gallipoli campaign from that moment, telling his soldiers, "I do not expect you to attack. I order you to die!" For his valor and decisive leadership, he was awarded the German Iron Cross and promoted to the rank of colonel. Throughout the rest of WWI, he consistently took the initiative in combat, demonstrating vision, solid instinct, the courage of his convictions, and the capacity for yet more responsibility. Fighting the Russians in Eastern Turkey, he won against numerically superior forces through the art of maneuver. During this time, Ataturk witnessed the fate of Turkish women and began to conceive how to better their lot, including abolishing the veil, elevating women's status in society through education and equality, and modernizing the country as a whole.

After WWI, the defeated Ottoman Empire seemed at the mercy of their foes, the victorious British, French, Italians, Armenians, and Greeks. But by astute political and military maneuvers, Ataturk harnessed Turkish nationalism. With minimal forces, little money, and no diplomatic status, he led the decimated Ottomans from disaster to an independent Turkish state. Against Greek invaders and their British allies, he used the telegraph for operational communications and spreading propaganda, which led to a political and cultural revolution and preserved Turkish territorial integrity.

Austin Bay's book is a must-read for Ataturk enthusiasts, Turkish history buffs, and students of leadership. Despite the aforementioned flaws, the work presents a solid, credible portrait of a visionary leader who transformed his country through sheer force of will.

Mark Roberts, Transportation Security Administration 
Journal of Strategic Security, Vol. 5, No. 1

Journal of Strategic Security

https://digitalcommons.usf.edu/jss/vol5/iss1/2

DOI: http://dx.doi.org/10.5038/1944-0472.5.1.7 